Annals of Warsaw University of Life Sciences - SGGW

Land Reclamation No 44 (1), 2012: 63-73

(Ann. Warsaw Univ. of Life Sci. - SGGW, Land Reclam. 44 (1), 2012)

\title{
A study of application of chalcedonite as a manganese dioxide carrier
}

\author{
MAGDALENA M. MICHEL
}

Department of Civil Engineering, Warsaw University of Life Sciences - SGGW

\begin{abstract}
A study of application of chalcedonite as a manganese dioxide carrier. Chalcedonite is a sedimentary siliceous rock, which occurs at four deposits in Poland and is included into a group of unique rocks. Chalcedonite is utilized in water treatment technology, mostly as an effective filtration material due to its mesoporous structure and extended outer surface of the grains. This paper presents three different methods of impregnation of the mineral material (MDMC-1, MDMC-2, MDMC-3) by manganese dioxide. As an oxide carrier chalcedonite was used. The results of the chalcedonite surface modification with SEM-EDS technique were presented. It was found that the chalcedonite is a very good manganese dioxide carrier and the modification of the chalcedonite surface changes its chemical composition, structure and value of the specific surface area.
\end{abstract}

Key words: chalcedonite, siliceous rocks, manganese dioxide, modified materials.

\section{INTRODUCTION}

Chalcedonite is a siliceous sedimentary rock and occurs at "Dęborzynka", "Gapinin", "Lubocz" and "Teofilów" deposits, located on the Rawska Plateau in the region of Tomaszów Mazowiecki and Nowe Miasto. Only the deposit "Teofilow" is documented and it is now being developed. The surface of this deposit is $577,437 \mathrm{~m}^{2}$ and its geological resources were estimated to be $21.587 \times$ $\times 10^{6} \mathrm{~kg}(21,587$ thousand ton) (Tchórzewska and Pabis 1997). The processing of the output consists of multiple breakages and sifting which ends in drying. It enables preparing the moisture-free material with particular fractions. The end product is chalcedonite sand with grains of $0.8-2.0 \mathrm{~mm}$ and gravel with the following grain sizes: $2.0-4.0 \mathrm{~mm}, 4.0-8.0$ $\mathrm{mm}, 8.0-16.0 \mathrm{~mm}$ and $16.0-32.0 \mathrm{~mm}$. The chalcedonite sand and gravel have a Hygienic Certificate PZH issued on the $31^{\text {st }}$ of July, 2008 (www.microsil.com.pl a). In the territory of the mine more than $1.2 \mathrm{mln} \mathrm{sq} \mathrm{m}$ of chalcedonite sand with the grains $\leq 2 \mathrm{~mm}$ is mined, it is deposited in a settling ditch (Kosk 2010).

The main component of the rock is chalcedony, but quartz, opal, ferric hydroxides, pyrite, manganese compounds and silty minerals also appear. The mineral composition of chalcedonite in volume percent is as follows: chalcedony, opal and autogenic quartz $68.3-95.4 \%$, quartz and other terrigenous components $0.3-6.6 \%$, free and filled pores 2.0-24.7\% (Ratajczak and Wyszomirski 1991). The fractions of chalcedony gathered in the settling ditches of the mine and used in the technology of water and wastewater treatment are characterized by a similar mineral composition: chalcedony and autogenic quartz 81.6$-88.6 \%$, terrigenous quartz $3.6-14.6 \%$, feldspars $0.3-1.7 \%$ and silty rock grits $2.0-8.5 \%$ (Kosk 2010). The chemical composition of chalcedonite is almost homogeneous because the content of silicon dioxide exceeds $94 \%$ and the 
analysis of the surface using the EDS technique showed spectral signals of silicon dioxide and oxygen (Michel 2011). The specific surface area is relatively small and was estimated to be $6.13 \mathrm{~m}^{2} / \mathrm{g}$ (Michel 2008a) and 3.25-8.67 $\mathrm{m}^{2} / \mathrm{g}$ (Ratajczak and Wyszomirski 1991). The specific density of the chalcedonite sand is comparable to that of quartz sand and is $2602 \mathrm{~kg} / \mathrm{m}^{3}$, and the bulk density for the fraction with the grain diameter in the range of $0.315-5.0 \mathrm{~mm}$ is $1306 \mathrm{~kg} / \mathrm{m}^{3}$. After consolidating the bulk density of the material increased to the value of $1538 \mathrm{~kg} / \mathrm{m}^{3}$ (Siwiec 2007).

Chalcedonite is a material with a wide range of application in the sanitary engineering. The basic application of the chalcedonite is water treatment, especially ground water. Its high usability unveils in good hydraulic properties of the material which allows obtaining large mass capacities on the filter and long filtration cycles. Many successful introductions were described when chalcedonite substituted classical filters of quartz sand (www.microsil.com.pl b). The structure of the filtration material, which chaldetonite is, its porosity and complex external surface of the grains can help to free development of the biofilm. It enables effective removal of ammonium from the underground water in the process of nitrification on the chalcedonite bed (Sozański et al. 2008). Chalcedonite does not have significant sorptive properties in relation to manganese(II) (Michel 2008a). Modification of its surface with manganese dioxide leads to creation of a chemically active material which shows effectiveness in manganese(II) removing in the second step filters. The usable capacity of the material prepared in this way was $0.76-4.0 \mathrm{~g} \mathrm{Mn} / \mathrm{L}$ of the bed, depending on the method of modification and the conditions of the research (Michel 2008a; Michel et al. 2008; Michel 2009). However, it can be taken into consideration as a sorptive material to remove oil spills. Regarding its abilities to soak in fuel and rape oil, the chalcedonite sand shows its effectiveness comparable to diatomite and clinoptilolite (Michel 2006).

Surface modification is a popular solution and as manganese dioxide carriers different materials are used, for instance, zeolite (Anielak 2006; Anielak and Schmidt 2011; Han et al. 2007), diatomite (Al-Degs et al. 2000; Al-Degs et al. 2001), montmorillonite (Boonfueng et al. 2005), bentonite (Eren et al. 2009), glauconite (www.purolite.com), quartz sand (Hu et al. 2004; Lee et al. 2004; Han et al. 2006), carbon nanotubes (Ma et al. 2007), aluminium oxide(III) (Maliyekkal et al. 2006) and polymeric fibre (Moore and Reid 1973; Su et al. 2009). In the water treatment technology for manganese(II) removal naturally made and synthetic filtration materials are used containing manganese dioxide in its composition (Kowal and Świderska-Bróż 2009). A high, negative surfacebound charge of $\mathrm{MnO}_{2}$ causes that it is a good sorbent of metals from water solutions. It has sorptive and catalytic properties which are used for water treatment from solved non-organic pollutions (Calderon Rosas et al. 2010). That is why it is a popular material used in the silt form or bound on the carrier.

The aim of this paper was to work out an effective method of manganese dioxide linking on the surface of the chalce- 
donite sand and to present the characteristic of the obtained material.

\section{EXPERIMENTAL}

\section{Sample preparation}

Chalcedonite sand used in the studies consisted of $0.8-1.25 \mathrm{~mm}$ grains. First it was washed with deionized water several times to remove particulate matter, and then it was dried in air conditions. The material was used to prepare manganese dioxide modified chalcedonite (MDMC). The chalcedonite coating was made using three methods.

The first method of MDMC preparation was similar to the one followed by Zhang et al. (2008). Manganese oxide was synthesized using the reaction of potassium permanganate with manganese(II) sulphate according to the formula:

$3 \mathrm{Mn}^{2+}+2 \mathrm{MnO}_{4}^{-}+2 \mathrm{H}_{2} \mathrm{O} \rightarrow 5 \mathrm{MnO}_{2}+$ $+4 \mathrm{H}^{+}$

$\mathrm{MnO}_{2}$ was precipitated when the reagents were mixed together and the reaction took place until manganese(II) sulphate was completely consumed (excess of potassium permanganate). The $100 \mathrm{~g}$ sample of chalcedonite was then placed in the manganese dioxide and potassium permanganate mixture for $24 \mathrm{~h}$ at the ambient temperature. The supernatant of this mixture was discarded and the chalcedonite soaked with manganese dioxide was dried in an oven at $100^{\circ} \mathrm{C}$ to consolidate the coating. The procedure was repeated twice. Next it was washed with deionized water, and then dried at $100^{\circ} \mathrm{C}$ to prepare the sample for analysis. The material prepared using this method will be referred to as MDMC-1.

The second method of chalcedonite surface modification was performed identically to modification of diatomite in the work of Al-Degs et al. (2001), which was adopted from the work of Moore and Reid (1973). Chalcedonite after modification was washed with deionized water, and then dried at $100^{\circ} \mathrm{C}$ to prepare the sample for analysis. The material prepared using this method will be referred to as MDMC-2.

The third method of MDMC preparation was described by Michel and Kiedryńska (2011). This method is similar to the first one but includes $\mathrm{MnO}_{2}$ precipitation in direct contact with the surface of the mineral carrier and binding with this surface. The finished sample was dried at $100^{\circ} \mathrm{C}$ just to prepare the material for analysis and $\mathrm{MnO}_{2}$ was not bound thermally with the surface of chalcedonite. The material prepared using this method will be referred to as MDMC-3. All solutions were prepared with redistilled water and reagent-grade chemicals.

\section{Material identification}

The samples of modified chalcedonite and their equivalents after the process of manganese(II) sorption were used as the material for the analysis. Sorption of the manganese(II) was conducted in the flow conditions, and the sorptive was prepared from the manganese(II) chloride and the redistilled water. The shape and elemental composition of the exterior surface of samples were analyzed using the SEM-EDS technique (scanning electron microscope by LEO Co. Ltd. fitted with an energy dispersive X-ray spec- 
trum detector by Oxford Instruments Ltd.). The samples consisted of $0.8-1.25$ $\mathrm{mm}$ grains and were not polished. Before analysis, they were coated with a thin layer of gold.

\section{RESULTS AND DISCUSSION}

Chalcedonit sand used for the research does not have a homogeneous grain structure. Chalcedonite is found in the deposit in two forms, that is why there are grains with a porous structure and an extensive external surface and solid grains with small surface development. More specific information on the topic is presented in the work of Michel (2011). The effects of the surface modification of chalcedonite in the current article is shown by the example of grains of porous variety.

The first method of impregnation which was based on thermal bound of the oxide with the surface of chalcedonite led to production of the grains thickly covered by the oxide. It is presented in Figure 1, which shows the overall view of the grain. On the MDMC-1 surface the layer is seen in which with the help

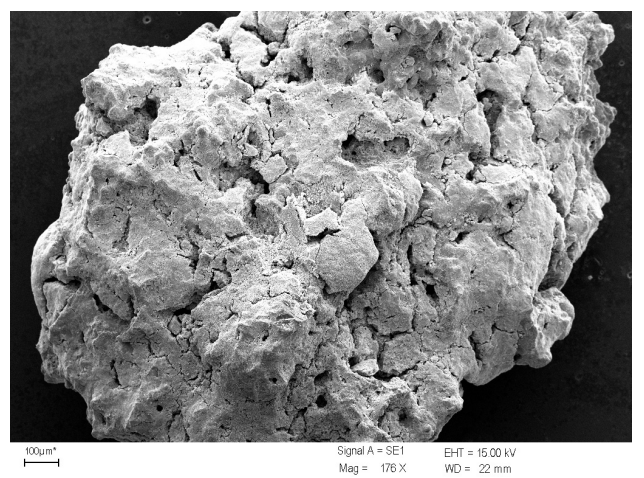

FIGURE 1. The SEM micrograph of the MDMC-1 grain of the EDS analysis the present of manganese coming from $\mathrm{MnO}_{2}$ was proved (Fig. 2). The large thickness of the coat causes that the spectral indication of silicon which comes from the bed was not observed. On the other hand, the obtained coat is not continuous and on its part it is subjected to exfoliation, which is clearly seen in Figure 3. The consequence of it was that in organoleptic observations the MDMC-1 material is left lose, pulverous particles of $\mathrm{MnO}_{2}$ come off the surface of the grains. The grains of the material

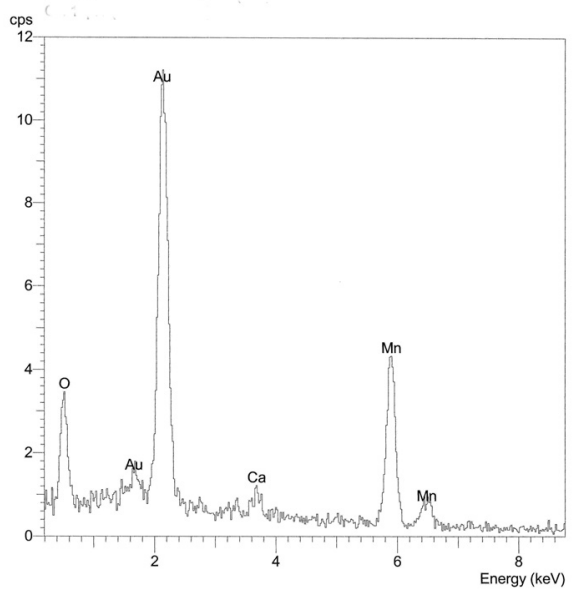

FIGURE 2. The EDS spectrum of the MDMC-1 coat

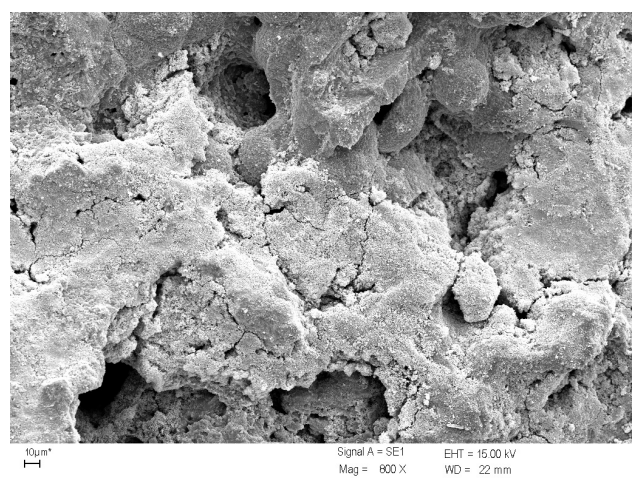

FIGURE 3. The SEM micrograph of the exfoliated MDMC-1 coat 
were of brown colour with visible clear parts in which the carrier was revealed. The coat made using the first method was characterized by low durability. $\mathrm{MnO}_{2}$ had a grain structure (Fig. 4) which is very similar to the surface of quartz sand coated with manganese oxide obtained by Han et al. (2006) using another method of impregnation. Modification of chalcedonite using this method causes an increase in its specific surface to the value of $8.36 \mathrm{~m}^{2} / \mathrm{g}$ (Michel 2008b). Sorption of the manganese(II) on MDMC-1 did not cause significant changes in the appearance of the coat (Fig. 5).

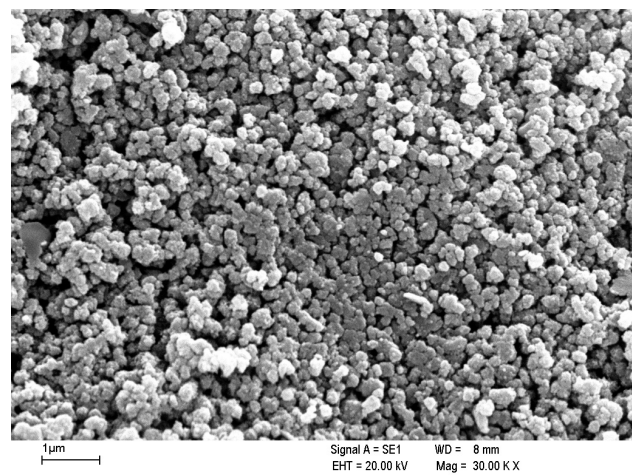

FIGURE 4. The SEM micrograph of the MDMC-1 coat grain structure

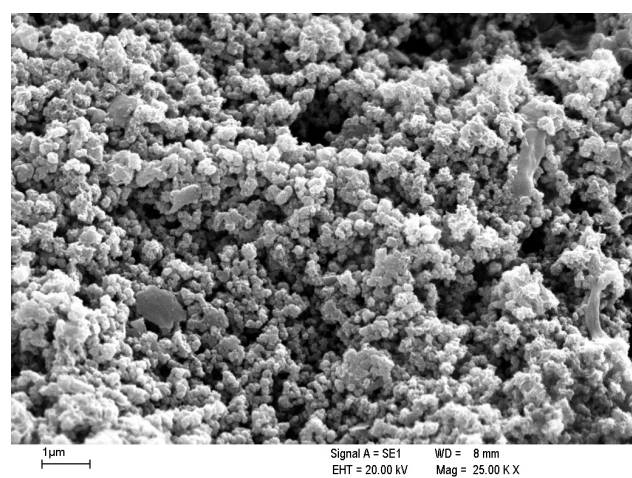

FIGURE 5. The SEM micrograph of the MDMC-1 coat structure after manganese(II) sorption
Chalcedonite modified using the second method was characterized by dark, black-brown colouring. The obtained coat was continuous. Figure 6 presents the overall view of the grain of the MDMC-2 material. Interstices and cavitations on the chalcesonite surface are filled with $\mathrm{MnO}_{2}$. The EDS analysis of the obtained layer shows strong spectral indication coming from manganese and weak indication of sodium which can be the remains of the preparation (Fig. 7).

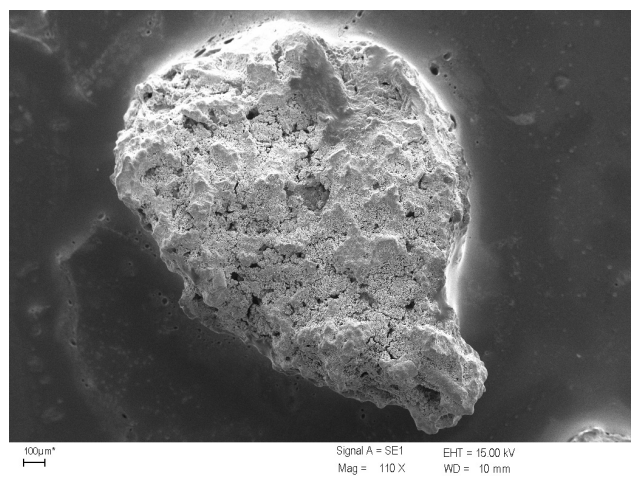

FIGURE 6. The SEM micrograph of the MDMC-2 grain

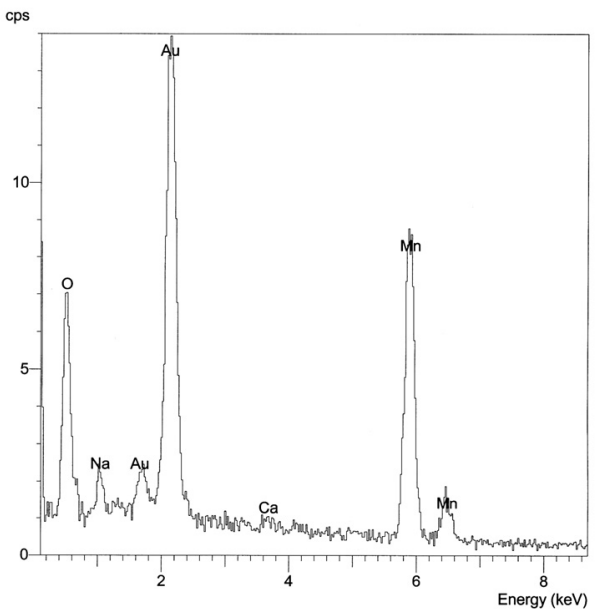

FIGURE 7. The EDS spectrum of the MDMC-2 coat (Michel et al. 2008) 
The coat has an irregular and crater structure (Fig. 8), which probably causes an increase in the specific surface area of the modified material which is 10.25 $\mathrm{m}^{2} / \mathrm{g}$ (Michel et al. 2008) in relation to the carrier surface which is $6.13 \mathrm{~m}^{2} / \mathrm{g}$. When enlarged the plate-like structure of the oxide is seen (Fig. 9). After the process of sorption of manganese(II) on the MDMC-2 material, it was observed that the plates that appeared in the structure were larger and more distinct (Fig. 10). Al-Degs et al. (2001) follow Golden et al. (1986) that the plate-like crystals are typical of birnessite. It is then highly probable that the second method of im-

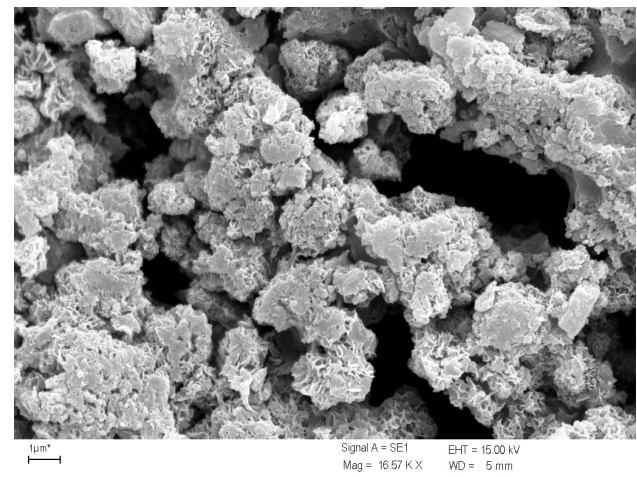

FIGURE 8. The SEM micrograph of the MDMC-2 coat crater structure

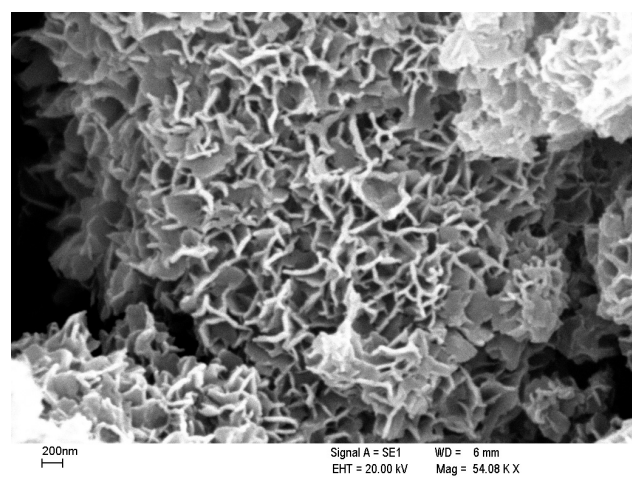

FIGURE 9. The SEM micrograph of the MDMC-2 coat plate-like structure

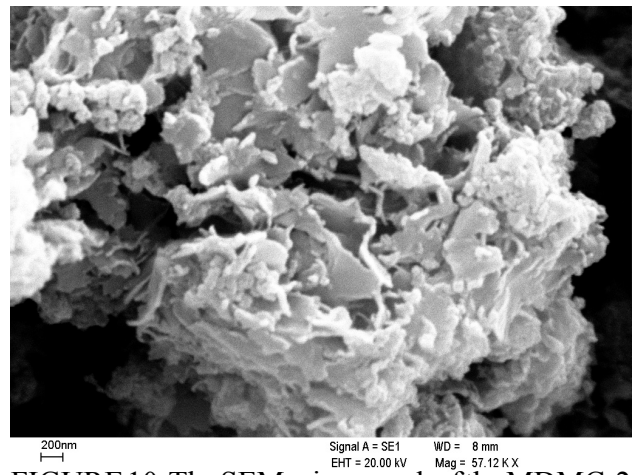

FIGURE 10. The SEM micrograph of the MDMC-2 coat plate-like structure after manganese(II) sorption

pregnation leads to appearance of exactly this kind of $\mathrm{MnO}_{2}$ on the chalcedonite.

The third method of modification of chalcedonie $\mathrm{MnO}_{2}$ leads to appearance of the brown, continuous coat which coats the whole grain surface (Fig. 11). The grain is not too much pasted over by the oxide whose larger concentration takes place only in the interstices (Fig. 12). In the organoleptic observations the MDMC-3 material is coherent and the obtained layer does not fracture. This effect was reached by precipitation of $\mathrm{MnO}_{2}$ in the direct contact with the carrier's surface. $\mathrm{MnO}_{2}$ has a grain structure seen in Figure 13. The EDS spectrum

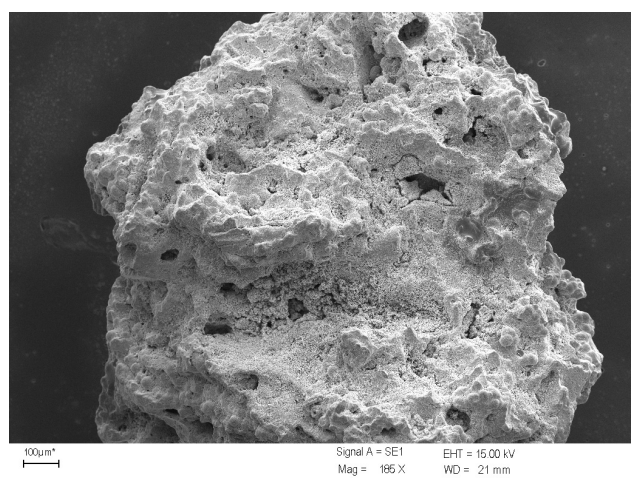

FIGURE 11. The SEM micrograph of the MDMC-3 grain 


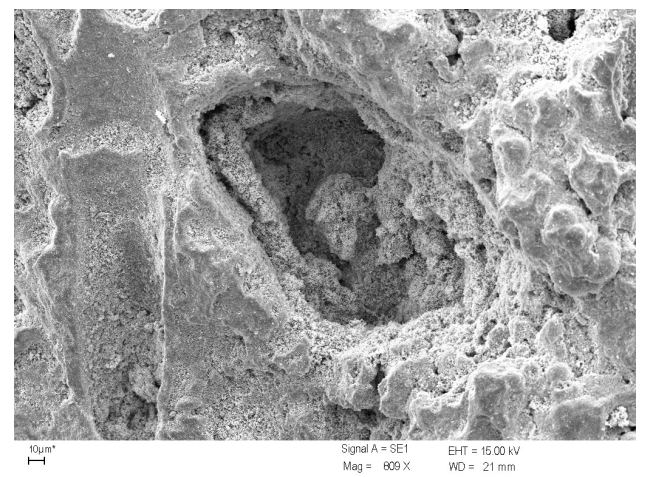

FIGURE 12. The SEM micrograph of the MDMC-3 coat structure

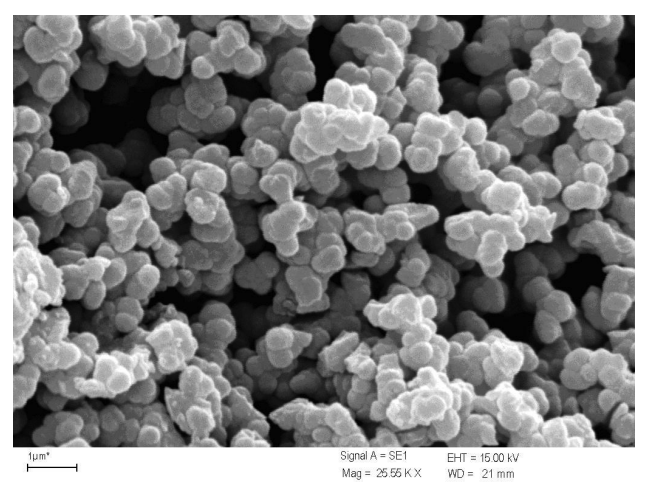

FIGURE 13. The SEM micrograph of the MDMC-3 coat grain structure (Michel 2008a)

of the MDMC-3 surface is presented in Figure 14. The spectral indication of manganese coming from the $\mathrm{MnO}_{2}$ coat and the spectral signal of silicon were observed too. It comes from chalcedonite $\left(\mathrm{SiO}_{2}\right)$ and may testify of a small thickness of the obtained coat. As a result of chalcedonite coating by $\mathrm{MnO}_{2}$ an increase in its specific surface area takes place. Its value of $6.13 \mathrm{~m}^{2} / \mathrm{g}$ increases to $9.88 \mathrm{~m}^{2} / \mathrm{g}$ (Michel 2008a). Sorption of manganese(II) ions causes a change in the appearance of the MDMC-3 material (Fig. 15). Manganese oxides in the form of $\mathrm{MnO}_{2}$ and $\mathrm{MnO}$ were identified on its surface (Michel 2008a). It is necessary

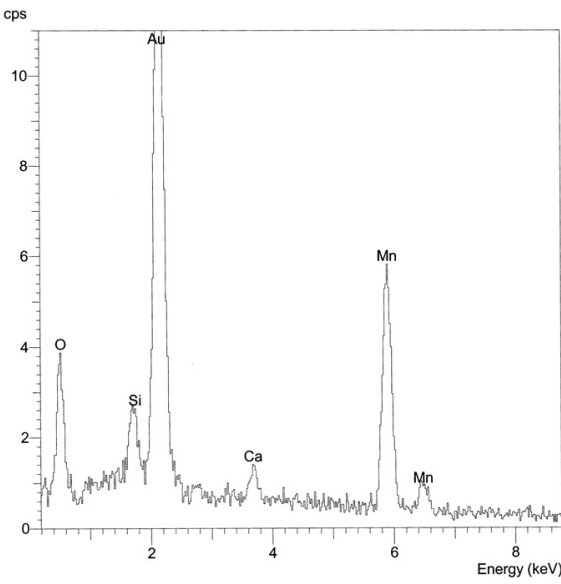

FIGURE 14. The EDS spectrum of the MDMC-3 coat

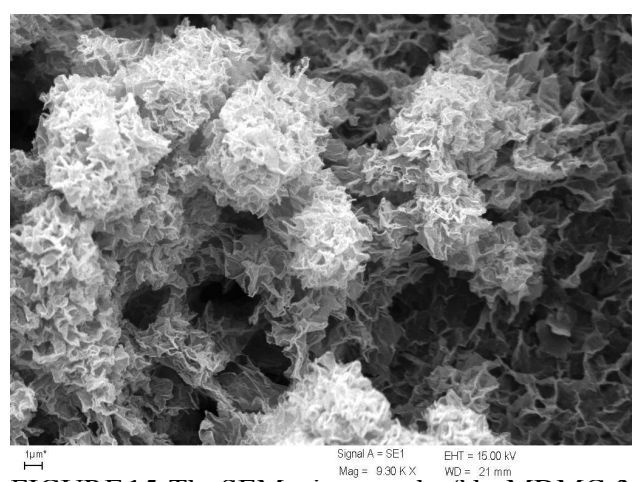

FIGURE 15. The SEMmicrograph of the MDMC-3 coat structure after manganese(II) sorption (Michel 2008a)

to point out that the grains of MDMC-3 as well as MDMC-1 and MDMC-2 after the process of manganese(II) sorption were not covered with biofilm.

The value of the specific surface of the MDMC-1, MDMC-2 and MDMC-3 materials is typical of this type of materials. For comparison, quartz sand modified with $\mathrm{MnO}_{2}$ can be characterized by the specific surface of $9.03 \mathrm{~m}^{2} / \mathrm{g}$ (Lee et al. 2004), $1.99 \mathrm{~m}^{2} / \mathrm{g}$ (Hu et al. 2004) and $0.712 \mathrm{~m}^{2} / \mathrm{g}$ (Han et al. 2006), whose 
variable values follow from the preparation of the material and the type of the carrier. The increase in the surface of the material as a result of modification of the carrier with $\mathrm{MnO}_{2}$ was also observed by other authors (Al-Degs et al. 2001; Han et al. 2006).

To sum it up, the used methods of impregnation allow making the modified material of different quality. The weakest effect was obtained when preparing MDMC-1 material with the thermal method. In comparison, the MDMC-2 and MDMC-3 material are much more durable. The MDMC-3 material is worth paying special attention at because an increased temperature is not used for its preparation (the increased temperature was used in order to prepare the sample with the constant moisture parameters). Taking into account the preparation of the modified chalcedonite in technological scale the second impregnation method is more complicated than the third one as the use of hot $\mathrm{NaOH}$ requires special security safeguards. Additionally, it is possible to carry out the modification of the filtrating material by the third method in the flow conditions.

\section{CONCLUSIONS}

Chalcedonite is a very good manganese dioxide carrier. The modification of the chalcedonite surface changes its chemical composition structure. The value of the specific surface of chalcedonite increases as a result of the modification in the MDMC- $1<$ MDMC- $3<$ MDMC -2 line. The coat morphology and structure depends on the applied impregnation method. The MDMC-3 material was considered to be the optimal regarding the strength of the coat and the easiness of its production.

The chalcedonit sand was used as a silica carrier for manganese oxides. The suggested methods of coating of chalcedonite by $\mathrm{MnO}_{2}$ can be potentially applied to other filtrating materials such as diatomite, clinoptylolite or pumice.

Chalcedonite is a very useful material in the water treatment technology. It can be easily affected by coating with an oxide layer; moreover its gains have a meso- and macroporous structure and irregular surface what corresponds to good filtrating properties of this material. It was stated on the manufacturer's website in the form of letters of reference from different water works plants. That is why chalcedonite sand is worth being looked at as a filling of filtering and chemically active beds, especially as its resources for exploitation are enough to be exported and the price is comparable to the price of quartz sand used for filtration.

\section{REFERENCES}

AL-DEGS Y., TUTUNJU M.F., SHAWABKEH R.A. 2000: The Feasibility of Using Diatomite and Mn-Diatomite for Remediation of $\mathrm{Pb}^{2+}, \mathrm{Cu}^{2+}$, and $\mathrm{Cd}^{2+}$ from Water. Separ. Sci. Technol. 35: 2299-2310.

AL-DEGS Y., KHRAISHEH M.A.M., TUTUNJU M.F. 2001: Sorption of lead ions on diatomite and manganese oxides modified diatomite. Water Res. 35: 3724-3728.

ANIELAK A.M. 2006: Właściwości fizykochemiczne klinoptylolitu modyfikowanego ditlenkiem manganu [The physicochemical properties of manganese dioxide-modified clinoptylolite]. Przem. Chem. 85: 487-491. 
ANIELAK A.M., SCHMIDT R. 2011: Sorption of lead and cadmium cations on natural and manganese-modified zeolite. Pol. J. Environ. Stud. 20 (1): 15-19.

BOONFUENG T., AXE L., XU Y. 2005: Properties and structure of manganese oxide-coated clay. J. Colloid Interf. Sci. 281: 80-92.

CALDERONROSASC.A.,FRANZREBM., VALENZUELA F., HÖLL W.H. 2010: Magnetic manganese dioxide as an amphoteric adsorbent for removal of harmful inorganic contaminants from water. Reactive \& Functional Polymers 70: 516-520.

EREN E., AFSIN B., ONAL Y. 2009: Removal of lead ions by acid activated and manganese oxide-coated bentonite. J. Hazard. Mater. 161: 677-685.

GOLDEN D.C., DIXOAN J.B., CHEN C.C. 1986: Ion exchange, thermal transformations, and oxidizing properties of birnessite. Clays Clay Minerals 34 (5): 511-520.

HAN R., ZOU W., ZHANG Z., SHI J., YANG J. 2006: Removal of copper(II) and lead(II) from aqueous solution by manganese oxide coated sand I. Characterization and kinetic study. J. Hazard. Mater. B137: 384-395.

HAN R., ZOU W., WANG Y., ZHU L. 2007: Removal of uranium(VI) from aqueous solutions by manganese oxide coated zeolite: discussion of adsorption isotherms and $\mathrm{pH}$ effect. J. Environ. Radioactivity 93: 127-143.

http://www.mikrosil.com.pl/index.php/jakosc-zloza/atest-pzh (20 April 2012 a).

http://www.mikrosil.com.pl/index.php/referencje-wdrozenia (20 April 2012 b).

HU P.-Y., HSIEH Y.-H., CHEN J.-C., CHANG C.-Y. 2004: Characteristics of manganese-coated sand using SEM and EDAX analysis. J. Colloid Interf. Sci. 272: 308-313.

KOSK I. 2010: Kompleksowe zagospodarowanie odpadowych surowców chalcedonitowych z osadników kopalni Inowłódz w ochronie środowiska oraz w przemyśle materiałów budowlanych [Complex management of chalcedonite waste fractions from inowłódz mine clarifiers in environment prevention and in building materials industry]. Gosp. Sur. Min. 26 (1): 5-22.

KOWAL A.L., ŚWIDERSKA-BRÓŻ M. 2009: Oczyszczanie wody [Water purification]. Polish Scientific Publishers PWN, Warsaw.

LEE C.-I. YANG W.-F. HSIEH C.-I. 2004: Removal of copper(II) by manganesecoated sand in a liquid fluidized-bed reactor. J. Hazard. Mater. B 114: 45-51.

MA S.-B., AHN K.-Y., LEE E.-S., OH K.-H., KIM K.-B. 2007: Synthesis and characterization of manganese dioxide spontaneously coated on carbon nanotubes. Carbon 45: 375-382.

MALIYEKKAL S.M., SHARMA A.K., PHILIP L. 2006: Manganese-oxidecoated alumina: A promising sorbent for defluoridation of water. Water Res. 40: 3497-3506.

MICHEL M.M. 2006: Sorpcja oleju na złożach mineralnych [The sorption of oil on the mineral beds]. Przeglad Naukowy Inżynieria $i$ Ksztaltowanie Środowiska SGGW 33 (1): 95-102.

MICHEL M.M. 2008a: Usuwanie jonów manganu(II) $\mathrm{z}$ roztworów wodnych na chalcedonicie naturalnym i modyfikowanym [Removal of manganese(II) from aqueous solution by natural and modified chalcedonite]. Materials of $8^{\text {th }}$ International Conference „Water Supply and Water Quality" Poznań-Gniezno, Poland, Vol. 1: 557-569.

MICHEL M.M. 2008b: Zastosowanie chalcedonitu $\mathrm{w}$ procesach usuwania manganu z wód podziemnych [The application of chalcedonite in the processes of manganese removal from underground water]. $\mathrm{Ph}$. D. dissertation, Warsaw University of Life Sciences - SGGW, Warsaw.

MICHEL M. M. 2009: Odmanganianie wody podziemnej na modyfikowanym chalcedonicie [Groundwater Demanganization by Modified Chalcedonite]. Gaz, Woda i Technika Sanitarna 4: 22-26. 
MICHEL M.M. 2011: Charakterystyka chalcedonitu ze złoża Teofilów pod kątem możliwości wykorzystania w technologii uzdatniania wody i oczyszczania ścieków [Characteristics of chalcedonite from Teofilów deposit for possible use in technology of water and wastewater treatment]. Gosp. Sur. Min. 27: 49-67.

MICHEL M.M., KIEDRYŃSKA L., TYSZKO E. 2008: Badania skuteczności odmanganiania wody podziemnej na modyfikowanym chalcedonicie i masie katalitycznej Purolite MZ-10 [Manganese removal from groundwater on modified chalcedonite and Purolite MZ-10 beds]. Ochrona Środowiska 3: 15-20.

MICHEL M.M., KIEDRYŃSKA L. 2011: Modelling equilibrium data for manganese(II) sorption onto manganese dioxide modified chalcedonite using the non-linear regression method. Ann. Warsaw Univ. of Life Sci. - SGGW, Land Reclam. 43 (2): 155-163.

MOORE W.S., REID D.F. 1973: Extraction of radium from natural waters using manganese - impregnated acrylic fibers. J. Geophysical Res. 36: 8880-8886.

Purolite Product Guide. Characteristics and Applications. The Purolite Company, 2011. http://www.purolite.com/Customized/Uploads/Purolite\%20Product $\% 20 \mathrm{~S}$ ummary\%20Guide.pdf (20 April 2012).

RATAJCZAK T., WYSZOMIRSKI P. 1991: Charakterystyka mineralogiczno-surowcowa chalcedonitów spongiolitowych z Teofilowa nad Pilicą [Mineralogical and technological characteristics of spongolithic chalcedonites of Teofilów on Pilica]. Gosp. Sur. Min. 7 (1): 65-84.

SIWIEC T. 2007: Warunki płukania jednowarstwowych i dwuwarstwowych filtrów pospiesznych [Conditions for backwashing of monolayers and duolayers rapid filters]. Warsaw University of Life Sciences - SGGW, Warsaw.

SOZAŃSKI M.M., WEBER Ł., JEŻ-WALKOWIAK J. 2008: Usuwanie jonów amonowych z wody podziemnej. Badania pilotowe na stacji uzdatniania wody
„Odra” w Świnoujściu [Removal of ammonia ions from groundwater. Results of pilot studies on wtp „Odra” in Świnoujście]. Materials of $8^{\text {th }}$ International Conference „Water Supply and Water Quality" Poznań-Gniezno, Poland, Vol. 1: 683-697.

TCHÓRZEWSKA D., PABIS J. 1997: Dodatek nr 2 do dokumentacji geologicznej złoża chalcedonitu „Teofilów” w kat. $\mathrm{B}+\mathrm{C}_{1}+\mathrm{C}_{2}$. Instytut Ceramiki i Materiałów Budowlanych, Kraków. [The appendix No. 2 to the geological documentation of the "Teofilów" deposit in cadastres $\mathrm{B}+\mathrm{C}_{1}+\mathrm{C}_{2}$. Archives of the Institute of Ceramics and Building Materials, Cracow].

SU Q., PAN B., PAN B., ZHANG Q., ZHANG W., LV L., WANG X., WU J., ZHANG Q. 2009: Fabrication of polymer-supported nanosized hydrous manganese dioxide (HMO) for enhanced lead removal from waters. Sci. Total Environ. 407: 5471-5477.

ZHANG L., MA J., YU M. 2008: The microtopography of manganese dioxide formed in situ and its adsorptive properties for organic micropollutants. Solid State Sciences 10: 148-153.

Streszczenie: Badania nad zastosowaniem chalcedonitu jako nośnika tlenku manganu. Chalcedonit jest osadową skałą krzemionkową, która występuje w Polsce w czterech złożach i jest zaliczana do grupy skał unikalnych. Chalcedonit jest wykorzystywany $\mathrm{w}$ technologii uzdatniania wody głównie jako efektywny materiał filtracyjny, na co wpływa jego mezoporowata struktura oraz rozwinięta zewnętrzna powierzchnia ziaren. W artykule zaprezentowano trzy metody modyfikacji materiału mineralnego (MDMC-1, MDMC-2 , MDMC-3) za pomoca tlenku manganu(IV). Chalcedonit był zastosowany jako nośnik tlenku. Zaprezentowane zostały efekty modyfikacji powierzchni chalcedonitu identyfikowane techniką SEM-EDS. Stwierdzono, że chalcedonit jest bardzo dobrym nośnikiem tlenku manganu(IV) a modyfikacja jego powierzchni zmienia jej skład chemiczny, strukturę oraz wielkość powierzchni właściwej. 
Stowa kluczowe: chalcedonit, skała krzemionkowa, tlenek manganu(IV), materiały modyfikowane.

MS. received May 2012

\section{Author' address:}

Magdalena M. Michel

Katedra Inżynierii Budowlanej

Wydział Budownictwa i Inżynierii Środowiska

Szkoła Główna Gospodarstwa Wiejskiego

ul. Nowoursynowska 159

02-776 Warszawa, Poland

e-mail: magdalena_michel@sggw.pl 